\title{
High Particulate Matter Burden of Cigarettes from the United Arab Emirates and Germany: Are There Country-Specific Differences?
}

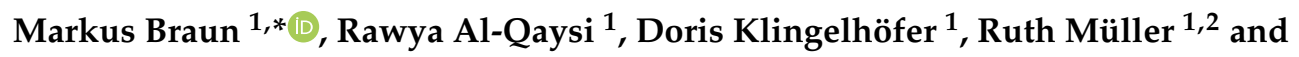 \\ David A. Groneberg ${ }^{1}$ \\ 1 Institute of Occupational Medicine, Social Medicine and Environmental Medicine, Goethe University \\ Frankfurt, Theodor-Stern-Kai 7, D-60590 Frankfurt am Main, Germany; rawya.alqaysi@yahoo.de (R.A.-Q.); \\ klingelh@med.uni-frankfurt.de (D.K.); ruth.mueller@med.uni-frankfurt.de (R.M.); \\ groneberg@med.uni-frankfurt.de (D.A.G.) \\ 2 Medical Entomology, Department of Biomedical Sciences, Institute of Tropical Medicine, Nationalestraat 155, \\ B-2000 Antwerpen, Belgium \\ * Correspondence: m.braun@med.uni-frankfurt.de; Tel.: +49-696-3018-7653
}

Received: 9 March 2020; Accepted: 1 April 2020; Published: 2 April 2020

\begin{abstract}
Although the big tobacco companies offer the same cigarette brands across countries, little is known about the potential regional differences of the particulate matter (PM) emissions of apparently equal brands. PM emissions of three cigarette brands (Marlboro Gold, Winston Red resp. Classic, Parliament Platinum resp. Night Blue) from the United Arab Emirates (UAE) and Germany were analysed. Second-hand smoke was produced in a $2.88 \mathrm{~m}^{3}$ measuring cabin by an automatic environmental tobacco smoke emitter. PM size fractions $\mathrm{PM}_{10}, \mathrm{PM}_{2.5}$, and $\mathrm{PM}_{1}$ were detected in real-time using laser aerosol spectrometry. Depending on the PM fraction Marlboro cigarettes from UAE showed 33\%-35\% higher PM amounts. Moreover, Winston cigarettes from UAE showed distinctly higher PM values (28-31\%) than the German counterparts. The "lighter" Parliament from UAE emitted 3\%-9\% more PM than the German one. The measured mean $\mathrm{PM}_{10}$ values laid between 778 and $1163 \mu \mathrm{g} / \mathrm{m}^{3}$ (mean PM $2.5: 777-1161 \mu \mathrm{g} / \mathrm{m}^{3}$; mean $\mathrm{PM}_{1}: 724-1074 \mu \mathrm{g} / \mathrm{m}^{3}$ ). That means smoking in enclosed rooms causes massive PM burden. The PM emission of equal or similar tobacco products from different countries can differ distinctly. Hence, the declaration of PM emission values, besides nicotine, tar, and carbon monoxide amounts, should be obligatory worldwide. Furthermore, complete information about the ingredients and production processes of tobacco products should be provided to health officials and the public. This can help to minimise or ban substances or product designs that make smoking even more harmful, and to enhance the awareness of the risks of smoking.
\end{abstract}

Keywords: second-hand smoke; environmental tobacco smoke; indoor air pollution; tobacco control; tobacco products; declaration of tobacco ingredients

\section{Introduction}

The big players of the global tobacco market offer the same cigarette brands across countries. However, the apparently identical brands may differ in production site, the origin of tobacco and, therefore, in ingredients. Hence, it is safe to assume that particulate matter (PM) emissions also vary across countries.

PM, a mixture of solid and liquid airborne particles, is classified by the United States Environmental Protection Agency (EPA) in $\mathrm{PM}_{10}$ (diameter $\leq 10 \mu \mathrm{m}$ ) and $\mathrm{PM}_{2.5}$ (diameter $\leq 2.5 \mu \mathrm{m}$ ). The EPA defines particles between 2.5 and $10 \mu \mathrm{m}$ as coarse inhalable particles and particles $\leq 2.5 \mu \mathrm{m}$ as fine inhalable 
particles [1]. The standard ISO 7708:1995 of the International Organization of Standardization (ISO) defines health-related PM size fractions by the deposition in the respiratory tract [2,3]. Such small particles can get deep into the respiratory system and even into the bloodstream. The smaller the particles, the deeper the regions they can get in, and the more adverse are the potential health effects [4]. It is reported that ultrafine particles (UFP; $<100 \mathrm{~nm}$ ) can reach the head region and the brain probably via the olfactory bulb [5]. PM is associate with a variety of serious health effects, especially heart and respiratory diseases, which can prove to be fatal [6]. The International Agency for Research on Cancer (IARC) of the World Health Organization (WHO) classifies PM as carcinogenic to humans [7]. In general, the higher the exposure to PM, the higher are morbidity and mortality [8]. Lim et al. [9] estimated in a comparative risk assessment for the year 2010 about 3.1 million cases of death caused by PM worldwide. The WHO even stated that 4.2 million cases of premature death have been caused by ambient air pollution and 3.8 million cases have been caused by indoor air pollution [10].

There are many sources of PM both indoor and outdoor [11]. Second-hand smoke (SHS), also known as environmental tobacco smoke, is mainly composed of smoke from the smouldering tobacco product and, with a minor part, of exhaled mainstream smoke from the smoker. It is the main indoor source of PM in households of smokers [12]. High levels of particle-bound polycyclic aromatic hydrocarbons (PAHs), whereof several are carcinogenic, were found in smokers' homes [13].

The present investigation aimed to ascertain if any country-specific differences of PM emissions by tobacco smoke are detectable. Two apparently identical pairs of two cigarette brands (Marlboro, Winston) and additionally a "light" and a "normal" type of the same brand (Parliament) sold in the United Arab Emirates (UAE) and Germany (GER) were examined regarding PM in SHS. This seems to be reasonable because previous studies showed a wide range of PM levels within different tobacco products [14-17]. The high-income countries UAE and Germany were chosen due to their similarities in a socioeconomic context [18].

Nevertheless, the UAE and Germany differ regarding tobacco consumption and its consequences in various ways. As maintained by The Tobacco Atlas of the American Cancer Society [19], in 2015, more than 1,342,000 adult people (15+ years old) in the UAE used a tobacco product each day, meaning $21.6 \%$ of men and $1.9 \%$ of women of its people. In Germany, the number was more than $15,341,000$ adult people ( $25.1 \%$ of men and $17.1 \%$ of women of its people), who use tobacco products daily. Thus, the prevalence of female smoking is in the UAE is much lower than in Germany. In 2016, deaths caused by tobacco were, in the UAE, 2900 of its people lower than the average in very-high-HDI (Human Development Index) countries (male $12.84 \%$, female $6.05 \%$ of total number of deaths). In Germany, the numbers are higher than on average in very-high-HDI countries given that more than 124,800 people died owing to tobacco consumption (male $18.42 \%$ and female $8.93 \%$ of the total number of deaths). According to The Tobacco Atlas, smoke-free policies are stronger in the UAE than in Germany, especially in healthcare and educational facilities. Additionally, bans on advertising are more extensive in the UAE. For example, in Germany, billboard and outdoor advertising, and advertising at selling points are still allowed.

\section{Materials and Methods}

\subsection{Tobacco Products}

The 3R4F reference cigarette developed by the Kentucky Tobacco Research and Development Center of the University of Kentucky, USA, [20] served as the standard of comparison for each three cigarette brands from the UAE and Germany. The UAE cigarettes were bought at an International Airport of Dubai and are as follows: Marlboro Gold [21], Winston Red [22], and Parliament Platinum [21]. The cigarettes from Germany were bought at an International Airport of Frankfurt and are as follows: Marlboro Gold [21,23], Winston Classic [22,23], and Parliament Night Blue [21,23]. Marlboro Gold and the two Parliament brands were produced by Philip Morris GmbH in Germany for the market of both countries. For the German market, Winston Classic cigarettes were manufactured by Japan 
Tobacco International (JTI) in Germany, whereas Winston Red from the UAE were produced by JTI in Switzerland. Table 1 shows some characteristics of all investigated tobacco products, whereby information on the manufacturer and amounts of nicotine, tar, and carbon monoxide were taken from the respective cigarette pack. The sizes and weights are given as measured means of five randomly chosen cigarettes of each brand.

Table 1. Features of the tested cigarette brands. The cigarette dimensions and weights are the mean values of five randomized chosen cigarettes of each brand. UAE $=$ United Arab Emirates. GER = Germany.

\begin{tabular}{|c|c|c|c|c|c|c|c|}
\hline $\begin{array}{l}\text { Cigarette Brand } \\
\text { (Country of } \\
\text { Origin) }\end{array}$ & $\begin{array}{c}\text { Reference } \\
\text { Cigarette 3R4F } \\
\text { (USA) }\end{array}$ & $\begin{array}{l}\text { Marlboro } \\
\text { Gold } \\
\text { (UAE) }\end{array}$ & $\begin{array}{l}\text { Marlboro } \\
\text { Gold } \\
\text { (GER) }\end{array}$ & $\begin{array}{l}\text { Winston } \\
\text { Red } \\
\text { (UAE) }\end{array}$ & $\begin{array}{l}\text { Winston } \\
\text { Classic } \\
\text { (GER) }\end{array}$ & $\begin{array}{l}\text { Parliament } \\
\text { Platinum } \\
\text { (UAE) }\end{array}$ & $\begin{array}{l}\text { Parliament } \\
\text { Night Blue } \\
\text { (GER) }\end{array}$ \\
\hline $\begin{array}{l}\text { Manufacturer } \\
\text { (Production } \\
\text { location) }\end{array}$ & $\begin{array}{l}\text { KTRDC Univ. } \\
\text { of Kentucky } \\
\text { (USA) }\end{array}$ & $\begin{array}{l}\text { Philip } \\
\text { Morris } \\
\text { GmbH } \\
\text { (GER) }\end{array}$ & $\begin{array}{l}\text { Philip } \\
\text { Morris } \\
\text { GmbH } \\
\text { (GER) }\end{array}$ & $\begin{array}{c}\text { Japan } \\
\text { Tobacco } \\
\text { International } \\
\text { (Switzerland) }\end{array}$ & $\begin{array}{c}\text { Japan } \\
\text { Tobacco } \\
\text { International } \\
\text { (GER) }\end{array}$ & $\begin{array}{l}\text { Philip } \\
\text { Morris } \\
\text { GmbH } \\
(\text { GER) }\end{array}$ & $\begin{array}{l}\text { Philip } \\
\text { Morris } \\
\text { GmbH } \\
\text { (GER) }\end{array}$ \\
\hline Nicotine [mg] & 0.73 & 0.5 & 0.5 & 0.6 & 0.8 & 0.1 & 0.8 \\
\hline Tar [mg] & 9.4 & 6 & 6 & 7 & 10 & 1 & 10 \\
\hline $\begin{array}{c}\text { Carbon } \\
\text { Monoxide [mg] }\end{array}$ & 12 & 7 & 7 & 7 & 10 & 1 & 10 \\
\hline $\begin{array}{l}\text { Total Length } \\
\text { [mm] }\end{array}$ & 84 & 83 & 83 & 84 & 83 & 83 & 98 \\
\hline $\begin{array}{l}\text { Total Weight } \\
\text { [mg] }\end{array}$ & 988 & 807 & 797 & 807 & 767 & 807 & 1045 \\
\hline $\begin{array}{l}\text { Tobacco Weight } \\
\text { [mg] }\end{array}$ & 775 & 599 & 580 & 653 & 642 & 600 & 755 \\
\hline $\begin{array}{l}\text { Filter Length } \\
{[\mathrm{mm}]}\end{array}$ & 27 & 27 & 27 & 21 & 21 & 22 & 22 \\
\hline $\begin{array}{l}\text { Filter Diameter } \\
{[\mathrm{mm}]}\end{array}$ & 8 & 8 & 8 & 8 & 8 & 8 & 8 \\
\hline
\end{tabular}

\subsection{Automatic Environmental Tobacco Smoke Emitter}

To generate SHS reproducibly, an Automatic Environmental Tobacco Smoke Emitter (AETSE) was used that was developed for the Tobacco Smoke Particles and Indoor Air Quality (ToPIQ) studies [14,24] and constructed by Schimpf-Ing. Trondheim, Norway [25]. The programmable microprocessor-controlled AETSE serves as a smoke pump and imitates the smoker. A 200-mL glass syringe, connected via a polyamide tube with the mouthpiece of the tobacco product, is moved by a stepper motor and take puffs of the tobacco product. After each puff, the smoke is pressed valve-controlled into the measuring chamber. The chamber with an internal volume of $2.88 \mathrm{~m}^{3}$ is closed during the smoke processes, avoiding the exposure of any person to tobacco smoke.

\subsection{Smoking Protocol}

The number of cigarettes analysed was $n=20$ for each tested type. All investigated cigarettes were smoked following the same modified protocol according to the ToPIQ studies [14,24]. The setting of the AETSE for the combustion phase, where each cigarette was lighted and smoked, was as follows: $40 \mathrm{~mL}$ puff volume; $13 \mathrm{~mL} / \mathrm{s}$ puff flow rate; 2 puffs/min; duration $3 \mathrm{~s} /$ puff; two ignition puffs followed by 7 regular puffs. This corresponds to a $4 \mathrm{~min} 22 \mathrm{~s}$ combustion phase. After that, each cigarette was extinguished followed by the $5 \mathrm{~min}$ post-combustion phase. Then, the air in the measuring chamber was cleaned by ventilating with an industrial radial fan for at least $5 \mathrm{~min}$. Subsequently, a new cycle began with a blank measurement in the pre-ignition phase. 


\subsection{Laser Aerosol Spectrometer}

The applied Laser Aerosol Spectrometer (LAS) and Dust Monitor Model 1.109 of Grimm Aerosol Technik GmbH \& Co KG (Ainring, Germany) [26] can detect airborne particles every six seconds in real-time. The measuring size ranges from 0.25 to $32 \mu \mathrm{m}$. The suction point of the LAS is placed $35 \mathrm{~cm}$ beside of the tobacco product at the same height. It is necessary to dilute the sample air pre-analytically using compressed air at a ratio of 1:10 to avoid blockage of the LAS measurement chamber. The dilution ratio was taken into account at the following data processing. Among others, the measured data can be represented in terms of occupational health according to the European Standard EN 481 [27], inhalable, thoracic, and alveolic in $\mu \mathrm{g} / \mathrm{m}^{3}$, and according to U.S. EPA as dust mass fractions $\mathrm{PM}_{10}, \mathrm{PM}_{2.5},[1]$ and additionally $\mathrm{PM}_{1}$ in $\mu \mathrm{g} / \mathrm{m}^{3}$.

\subsection{Data Processing}

For all investigated cigarettes, the mean concentrations $\left(C_{\text {mean }}\right)$ and the area under the concentration-time curve (AUC), meaning the total PM exposition, were calculated for data received during the $4 \mathrm{~min} 22 \mathrm{~s}$ of the combustion phase. All $\mathrm{C}_{\text {mean }}$ and AUC values were tested for Gaussian distribution that all data passed. Subsequently, a one-way analysis of variance (ANOVA) test and Tukey's multiple comparisons test were applied to show the differences between different types of cigarettes among themselves. Finally, a two-way ANOVA test, including Sidak's multiple comparisons test, was done to examine the country-specific differences. The level of significance was set on $p=0.05$. All statistical tests were done with GraphPad Prism version 8 (San Diego, CA, USA) software.

\section{Results}

Table 2 listed the $C_{\text {mean }}$ and AUC values of all investigated cigarette brands. Looking at the mean PM measurement results, both Marlboro and Winston cigarettes from UAE show significantly higher values than the German counterparts. The $C_{\text {mean }} \mathrm{PM}_{1}$ value of Marlboro UAE is $1074 \mu \mathrm{g} / \mathrm{m}^{3} 35 \%$ higher than the mean value of the Marlboro GER $\left(795 \mu \mathrm{g} / \mathrm{m}^{3}\right)$. The Winston UAE show a $28 \%$ higher $\mathrm{C}_{\text {mean }} \mathrm{PM}_{1}$ value $\left(929 \mu \mathrm{g} / \mathrm{m}^{3}\right)$ than those from Germany $\left(724 \mu \mathrm{g} / \mathrm{m}^{3}\right)$. The $C_{\text {mean }}$ value of $997 \mu \mathrm{g} / \mathrm{m}^{3}$ for $\mathrm{PM}_{1}$ of the Parliament UAE cigarettes is only a little higher $(9 \%)$ than that of the German $\left(917 \mu \mathrm{g} / \mathrm{m}^{3}\right)$. The UAE cigarettes of all three brands also show higher $\mathrm{PM}_{10}$ and $\mathrm{PM}_{2.5} \mathrm{C}_{\text {mean }}$ values. Accordingly, Marlboro UAE shows 33\% higher $\mathrm{PM}_{10}$ and $\mathrm{PM}_{2.5}$ mean values, and Winston UAE shows $31 \%$ and $30 \%$ higher values, respectively, than the German counterparts. Both Parliament brands show very similar $\mathrm{PM}_{10}$ and $\mathrm{PM}_{2.5}$ measurement results with only $3 \%$ higher values than the UAE type. Regarding the AUC values, similar findings emerged.

The two-way ANOVA test of the investigated pairs of cigarette brands revealed that the origin of the tobacco product has a higher influence on PM emissions than the brand (Figure 1). A pairwise comparison regarding the $\mathrm{p}$ values of the brands from UAE and Germany are shown in Table 3. The country-specific significance for $\mathrm{PM}_{1}$ is $p<0.0001$ (brand: $p=0.0114$ ). An interaction between brand and country is not significant $\left(p=0.123\right.$ ). Similar results pertain for $\mathrm{PM}_{2.5}$ (country: $p=0.0005$; brand: $p=0.0097$; interaction: $p=0.0907$ ) and $\mathrm{PM}_{10}$ (country: $p=0.0006$; brand: $p=0.0097$; interaction: $p=0.0892)$. 
Table 2. Mean concentrations $\left(\mathrm{C}_{\text {mean }} \mathrm{PM}_{10}, \mathrm{PM}_{2.5}\right.$ and $\left.\mathrm{PM}_{1}\right)$ and Area Under the Curve (AUC $\mathrm{PM}_{10}$, $\mathrm{PM}_{2.5}$ and $\mathrm{PM}_{1}$ ) with standard deviation of all tested tobacco products. UAE $=$ United Arab Emirates. GER $=$ Germany.

\begin{tabular}{|c|c|c|c|c|c|c|c|}
\hline $\begin{array}{l}\text { Cigarette Brand } \\
\text { (Country) }\end{array}$ & $\begin{array}{c}\text { Reference } \\
\text { Cigarette 3R4F } \\
\text { (USA) }\end{array}$ & $\begin{array}{c}\text { Marlboro } \\
\text { Gold } \\
\text { (UAE) }\end{array}$ & $\begin{array}{c}\text { Marlboro } \\
\text { Gold } \\
\text { (GER) }\end{array}$ & $\begin{array}{c}\text { Winston } \\
\text { Red } \\
\text { (UAE) }\end{array}$ & $\begin{array}{l}\text { Winston } \\
\text { Classic } \\
\text { (GER) }\end{array}$ & $\begin{array}{l}\text { Parliament } \\
\text { Platinum } \\
\text { (UAE) }\end{array}$ & $\begin{array}{c}\text { Parliament } \\
\text { Night Blue } \\
\text { (GER) }\end{array}$ \\
\hline $\begin{array}{c}\mathrm{C}_{\text {mean }} \mathrm{PM}_{10} \\
{\left[\mu \mathrm{g} / \mathrm{m}^{3}\right]}\end{array}$ & $1147 \pm 131$ & $1163 \pm 165$ & $874 \pm 284$ & $1016 \pm 367$ & $778 \pm 140$ & $1099 \pm 230$ & $1071 \pm 332$ \\
\hline $\begin{array}{c}\mathrm{C}_{\text {mean }} \mathrm{PM}_{2.5} \\
{\left[\mu \mathrm{g} / \mathrm{m}^{3}\right]}\end{array}$ & $1143 \pm 127$ & $1161 \pm 163$ & $872 \pm 282$ & $1013 \pm 365$ & $777 \pm 139$ & $1095 \pm 228$ & $1065 \pm 324$ \\
\hline $\begin{array}{c}\mathrm{C}_{\text {mean }} \mathrm{PM}_{1} \\
{\left[\mu \mathrm{g} / \mathrm{m}^{3}\right]}\end{array}$ & $1038 \pm 83$ & $1074 \pm 119$ & $795 \pm 228$ & $929 \pm 301$ & $724 \pm 109$ & $997 \pm 183$ & $917 \pm 184$ \\
\hline $\begin{array}{c}\mathrm{AUC} \mathrm{PM}_{10} \\
{\left[\mu \mathrm{g} / \mathrm{m}^{3} \mathrm{~s}\right]}\end{array}$ & $\begin{array}{c}993,700 \pm \\
114,216\end{array}$ & $\begin{array}{c}982,886 \pm \\
108,338\end{array}$ & $\begin{array}{c}756,938 \pm \\
245,919\end{array}$ & $\begin{array}{c}879,302 \pm \\
318,628\end{array}$ & $\begin{array}{c}673,982 \pm \\
121,369\end{array}$ & $\begin{array}{c}945,533 \pm \\
198,399\end{array}$ & $\begin{array}{c}927,093 \pm \\
287,701\end{array}$ \\
\hline $\begin{array}{c}\mathrm{AUC} \mathrm{PM}_{2.5} \\
{\left[\mu \mathrm{g} / \mathrm{m}^{3} \mathrm{~s}\right]}\end{array}$ & $\begin{array}{c}989,999 \pm \\
110,121\end{array}$ & $\begin{array}{c}981,310 \pm \\
107,531\end{array}$ & $\begin{array}{c}755,173 \pm \\
244,487\end{array}$ & $\begin{array}{c}877,279 \pm \\
317,060\end{array}$ & $\begin{array}{c}672,827 \pm \\
120,476\end{array}$ & $\begin{array}{c}943,460 \pm \\
197,337\end{array}$ & $\begin{array}{c}922,547 \pm \\
280,833\end{array}$ \\
\hline $\begin{array}{l}\text { AUC } \mathrm{PM}_{1} \\
{\left[\mu \mathrm{g} / \mathrm{m}^{3} \mathrm{~s}\right]}\end{array}$ & $\begin{array}{c}898,660 \pm \\
72,073\end{array}$ & $\begin{array}{c}913,681 \pm \\
83,482\end{array}$ & $\begin{array}{c}688,275 \pm \\
197,675\end{array}$ & $\begin{array}{c}803,915 \pm \\
261,703\end{array}$ & $\begin{array}{c}626,772 \pm \\
94,302\end{array}$ & $\begin{array}{c}863,535 \pm \\
158909\end{array}$ & $\begin{array}{c}793,771 \pm \\
159,949\end{array}$ \\
\hline
\end{tabular}

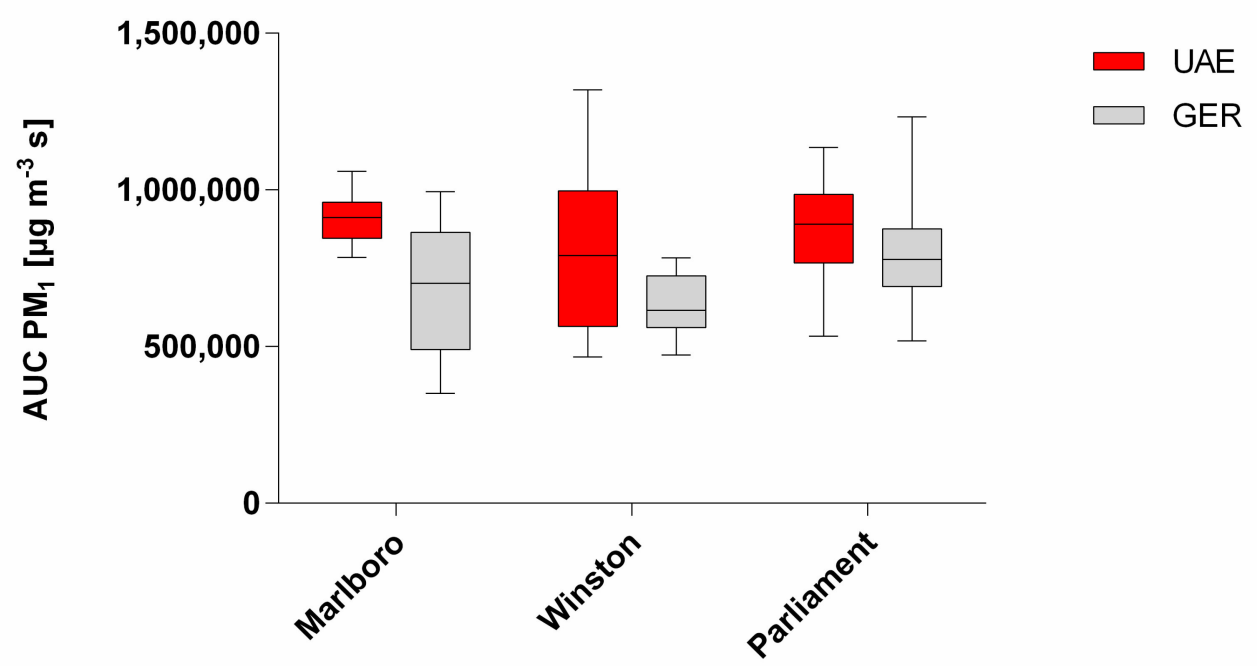

Figure 1. Comparative boxplot (min to max whiskers) of the area under the curve (AUC) $\mathrm{PM}_{1}$ of country-specific brands. The results are based on a statistical two-way analysis of variance (ANOVA) test. $\mathrm{UAE}=$ United Arab Emirates. GER $=$ Germany.

Table 3. $p$-values of statistical Sidak's multiple comparisons test of $C_{\text {mean }}\left(\mathrm{PM}_{10}, \mathrm{PM}_{2.5}, \mathrm{PM}_{1}\right)$ for the three cigarette brand pairs from the UAE and Germany.

\begin{tabular}{cccc}
\hline & Marlboro & Winston & Parliament \\
\hline $\mathrm{PM}_{10}$ & $\mathbf{0 . 0 0 2 6}$ & $\mathbf{0 . 0 1 9 4}$ & 0.9838 \\
\hline $\mathrm{PM}_{2.5}$ & $\mathbf{0 . 0 0 2 3}$ & $\mathbf{0 . 0 1 8 5}$ & 0.9791 \\
\hline $\mathrm{PM}_{1}$ & $<\mathbf{0 . 0 0 0 1}$ & $\mathbf{0 . 0 0 5 2}$ & 0.5171 \\
\hline
\end{tabular}

Statistical significance regarding the origin of tobacco product is highlighted by a bold font type. The significance level was set on $p=0.05$.

The $\mathrm{C}_{\text {mean }}$ and AUC values of Marlboro UAE do not differ significantly from the values of the reference cigarette. A little lower, but not significantly, are the values of Parliament UAE $(-4.2 \%$ for $\left.\mathrm{C}_{\text {mean }} \mathrm{PM}_{10}\right)$, Parliament GER (-6.6\% for $\left.\mathrm{C}_{\text {mean }} \mathrm{PM}_{10}\right)$ and Winston UAE $\left(-1.4 \%\right.$ for $\left.\mathrm{C}_{\text {mean }} \mathrm{PM}_{10}\right)$. 
Significantly lower compared to the reference cigarette are the values of the Marlboro GER $(-23.8 \%$ for $\left.\mathrm{C}_{\text {mean }} \mathrm{PM}_{10} ; p=0.0139\right)$ and the Winston GER $\left(-32.2 \%\right.$ for $\left.\mathrm{C}_{\text {mean }} \mathrm{PM}_{10} ; p=0.0002\right)$.

Regarding the distribution pattern of the particles $\mathrm{PM}_{10}, \mathrm{PM}_{2.5}$, and $\mathrm{PM}_{1}$ (Figure 2), it was ascertained for all investigated brands that the main part is represented by the $\mathrm{PM}_{1}$ fraction with a percentage from about $85 \%$ to $93 \%$. The proportion of $\mathrm{PM}_{10}$ is far below $1 \%$ for all brands.

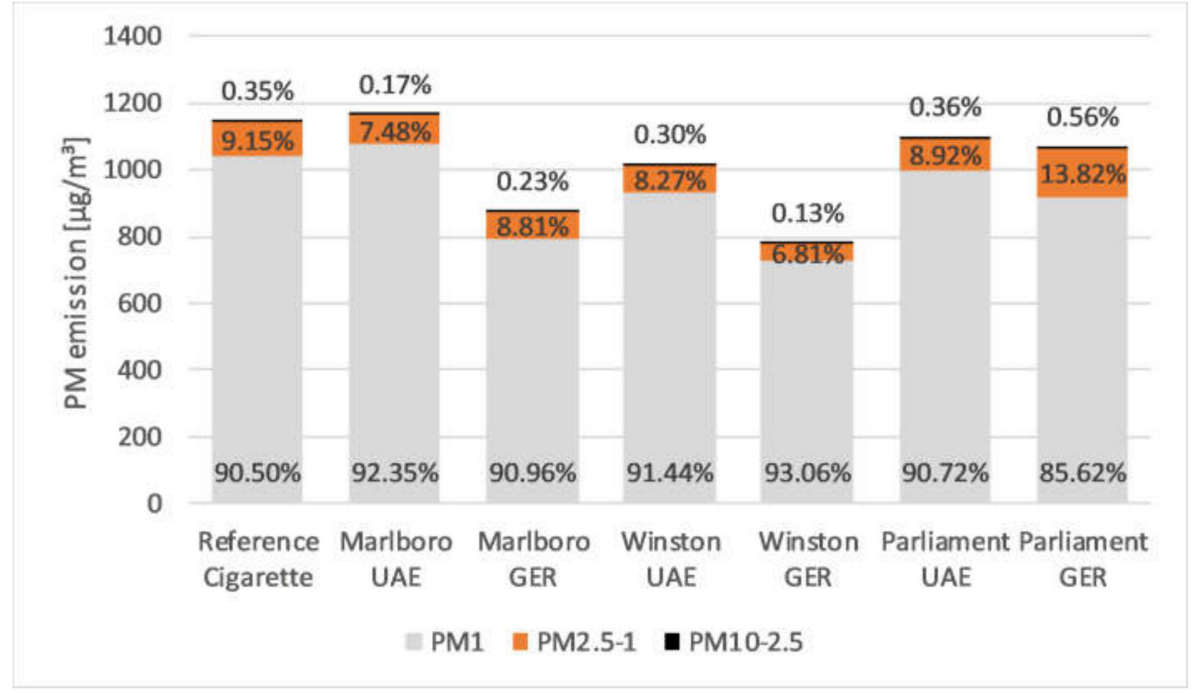

Figure 2. Distribution pattern of $\mathrm{PM}_{10-2.5}, \mathrm{PM}_{2.5-1}$, and $\mathrm{PM}_{1}$ in aerosol generated by the combustion of all investigated cigarettes. UAE $=$ United Arab Emirates. GER $=$ Germany.

\section{Discussion}

The measured $\mathrm{C}_{\text {mean }} \mathrm{PM}_{2.5}$ values were between $777 \mu \mathrm{g} / \mathrm{m}^{3}$ (Winston GER) and $1161 \mu \mathrm{g} / \mathrm{m}^{3}$ (Marlboro UAE). By way of comparison, the WHO limit value (24-h mean) for ambient air $\mathrm{PM}_{2.5}$ concentration is $25 \mu \mathrm{g} / \mathrm{m}^{3}$ [28]. In addition to this, the WHO air quality guideline pointed out that there is no safe level below which no risk for health exists by PM exposure [28]. This means smoking in closed rooms causes PM burden with strong exceedance of the WHO 24-h mean limit value accompanied by a considerably increased risk for adverse health effects. It would take hours until the PM values decrease to a level below the limit. Semple and Latif [29] ascertained in an analysis of $\mathrm{PM}_{2.5}$ amounts in SHS in households of smokers a PM half-life ( $50 \%$ PM decline) of about one hour.

The scenario of our study in the measuring cabin with an indoor volume of $2.88 \mathrm{~m}^{3}$ is comparable to the situation in a compact car with closed windows and turned off ventilation. This car class has a passenger and cargo volume of 2.832 to $3.087 \mathrm{~m}^{3}$ according to U.S. EPA [30] and, hence, a similar internal volume. Considering the very high PM burden caused by smoking in such small closed rooms and the associated health risks, a global ban on smoking in cars is to be in order, especially as children as car passengers are often affected.

Both tested Marlboro cigarettes, one type produced for the UAE sales market, and the other for the German market, were manufactured in Germany and had identical nicotine, tar, and carbon monoxide amounts. Nevertheless, our findings show that the UAE type emitted significantly more PM. The second investigated brand, Winston, from the UAE with lower amounts of nicotine, tar, and carbon monoxide emitted more PM too. Parliament GER and Parliament UAE showed very similar PM values, although the UAE type is a "lighter" version. Braun et al. [31] ascertained in an investigation of four cigarette types of one specific brand, all manufactured for the German market, that the lower the amounts of nicotine, tar, and carbon monoxide, the less PM is in the SHS. However, the results of our study suggest that smoking cigarettes from the UAE leads to a higher PM burden than smoking German cigarettes, especially at a similar tobacco strength. Looking at the six investigated brands, 
the high statistical significance of the country-specific differences in contrast to the obvious lower significance of the influence of the brand on PM emissions has to be emphasised.

The reasons for the varying PM emission values are not clear. However, it can be assumed that tobacco companies use country-specific tobacco blends and/or filters and/or cigarette paper for the respective tobacco market. A different composition of additives, different tobacco blend, or a combination of both are plausible reasons for our findings. The tobacco use in both countries differs in the choice of specific tobacco products as well as sociologically. First, it is worth mentioning that in the UAE the proportion of female smokers is very low, but the male smoking rates are much higher and comparable to those of Germany. According to the WHO Report on the Global Tobacco Epidemic, 2019 [32], the prevalence in the UAE of the current smoking of any tobacco product among persons aged $\geq 15$ years is $14.8 \%$ (male $29.1 \%$, female $0.6 \%$ ), and of cigarette smoking $11.4 \%$ (male $22.5 \%$, female $0.3 \%$ ). The respective data for Germany related to smoking any tobacco product is $28.4 \%$ (male $30.4 \%$, female $26.3 \%$ ) and of cigarette smoking $26.3 \%$ (male $28.1 \%$, female $26.3 \%$ ). In the Middle East, traditional and centuries-old tobacco use with a water pipe (i.e., hookah, shisha, narghile) is becoming more and more popular worldwide. This trend started in the 1990s among the Arab youth [33]. Al-Houqani et al. [34] reported in a large cross-sectional survey from 2008 to 2010 among 170,430 UAE nationals aged $\geq 18$ years that the prevalence of smoking a water pipe was in total $0.76 \%$ (male $1.67 \%$ ). This was trumped by the prevalence of smoking cigarettes (in total $8.55 \%$, male $18.77 \%$ ) and smoking Midwakh (in total 1.66\%, male 3.64\%). Midwakh, traditionally smoked by Bedouins and sailors of the Gulf States, is a small pipe for smoking dry tobacco (Dokha), often flavoured with spices and herbs [34]. In Germany, there exists no data about midwakh smoking, but the use of a midwakh might certainly be unusual. The prevalence of the current smoking of water pipes among German persons aged $\geq 15$ years is declared by the Special Eurobarometer 385 survey with 5\% [35]. Unfortunately, all this data is based on surveys and are, therefore, not consistent. In 2018, Al-Houqani et al. [36] compared in a pilot study the self-reported tobacco use of 399 UAE nationals with the validation of the smoking status via cotinine testing in urine samples. They found that $42 \%$ of men and $9 \%$ of women were positive for cotinine versus the self-reported tobacco use of $36 \%$ men and $3 \%$ women. This indicates that especially women in the UAE often conceal the use of tobacco. Nevertheless, all this elucidate significant differences in the use of tobacco between UAE and Germany.

Tobacco companies declare the exact composition, the "recipe" of the tobacco product, as "highly valuable trade secrets" [21,22,37]. O'Connor et al. [38] concluded in a comparison of cigarettes from ten different countries (low-, middle- and high-income) that the higher the country's economic level, the lower the emission levels due to a higher engineering of cigarette design and filters. On the other side, Song et al. [39] demanded a general ban on ventilated filters, which can be referred to as "highly engineered". Ventilated filters lead to a lower combustion temperature and the subsequent more incomplete combustion that increases the toxicity of tobacco smoke. Moreover, the smoker is tempted to inhale more intensively while smoking tobacco products with ventilated filters.

Previous study results regarding additives are inconsistent. On the one hand, Rustemeier et al. [40] stated in 2002 that additives in cigarettes increase PM levels in a range from $13 \%$ to $28 \%$. Braun et al. [17] found higher PM burden by cigarettes with additives in comparison to those of the same brand without additives too. An analysis of the formerly secret documents of the tobacco industry released in 2011 by Wertz et al. [41], ascertained post hoc protocol alterations in four peer-reviewed publications conducted by Philip Morris. In this way, the initial statistical findings that additives lead to an increase in toxicity as well as PM concentrations in tobacco smoke should be obscured. On the other hand, Wasel et al. [15] found no statistically significant increase of PM amount in cigarette smoke caused by additives in an investigation of four L\&M tobacco products, one type without additives. Gaworski et al. [42] and Gerharz et al. [43] examined cigarettes with the additive menthol. They could not prove an increase in neither toxicity nor PM burden caused by menthol.

A limitation of this study was that the used LAS Grimm Model 1.109 detects airborne particles in a size range of 0.25 to $32 \mu \mathrm{m}$, but not below. The detected particles of all brands were mainly composed 
by $\mathrm{PM}_{1}(85 \%-93 \%)$ depending on the brand. Only $0.13 \%$ to $0.56 \%$ were sized between 2.5 and 10 $\mu \mathrm{m}$ (Figure 2). This implies that a part of submicronic particles $(<1 \mu \mathrm{m})$ and UFPs $(<100 \mathrm{~nm})$ are not included in this analysis. Several studies reported different particle sizes (e.g., $0.1-1 \mu \mathrm{m}$ or $0.02-2 \mu \mathrm{m}$ ) and mean diameters (e.g., 0.1, 0.18, or $0.5 \mu \mathrm{m}$ ) of tobacco smoke [44-49]. Hence, it is safe to assume that the measured data of this study are slightly to low. Nevertheless, the applied LAS is able to detect most of the PM in SHS. However, since the adverse health effects of UFPs have come more and more into focus [50], an expansion of the measurement system would be useful.

The reference methods for measuring PM stated by the European Committee for Standardisation (see: standard EN 12341) [51] and the US EPA (see: Federal Reference Methods, FRM) [52] are mostly gravimetric methods. After a 24-h sample collection of PM, the sample filters will be weighed out to determine the mass concentrations of $\mathrm{PM}_{10}$ and $\mathrm{PM}_{2.5}$ without declaration of $\mathrm{PM}_{1}$. The LAS Grimm Model 1.109, which was used in this study, measures PM in real-time via light scattering like the Grimm Model EDM 180 or the Tapered Element Oscillating Microbalance (TEOM) Monitor, which are both FRMs too [52]. A study from 2009 showed very similar PM measuring data of the gravimetric methods, the TEOM Monitor, Grimm Model EDM 180, and the Grimm Model 1.109 [53]. Fromme et al. [54] noticed that PM values measured by LAS are lower than those of the gravimetric methods but with a very high correlation of the data rank order. Thus, it is essential not to change the measuring method or device during the investigation. Hence, the measuring data of the used LAS can be considered as valid. Besides, it has to be emphasised that the applied LAS enables us to investigate each single tobacco product in real-time.

There are several protocols for smoking regimes, but no "gold standard". Here, the standard of the International Organization of Standardization ISO/TR 17219:2013 for machine smoking of cigarettes [55] or the Standard Operating Procedure for Intense Smoking of Cigarettes provided by the WHO [56] shall be mentioned. The protocol underlying the current paper differs from these smoking regimes, but the provided results are likewise reliable and reproducible. The here applied AETSE produces SHS without exposing any person to tobacco smoke and concomitant health risks. The exact imitation of human smoking behaviour and SHS is not possible as true smoking humidifies the inhaled mainstream smoke in the respiratory tract. This leads to hygroscopic growth, and afterwards, the particles of the exhaled smoke are about 1.5-fold larger [57]. As SHS is a composite of about $85 \%$ side-stream smoke and only $15 \%$ mainstream smoke [58], the AETSE generates tobacco smoke that is very similar to SHS.

This study, much like to previous ToPIQ studies, focused on the comparison of the investigated tobacco products with a reference cigarette [14-17,24,31,43,59]. Especially for comparison with guideline values or other investigations, the absolute data are stated.

\section{Conclusions}

Especially in small settings and non-aerated rooms, smoking leads to massive PM burden. Even though the manufacturing locations are equal, the PM emissions of similar tobacco products from various countries can differ significantly. Tobacco products are manufactured for respective tobacco markets with different legal norms. Therefore, a global and consistent obligation to declare the amounts of nicotine, tar, carbon monoxide and PM amounts is useful and necessary. Additionally, it should be obligatory for tobacco companies to fully inform health officials, the public, and projects, e.g., DiMoPEx (Diagnosis, Monitoring and Prevention of Exposure-related Non-Communicable Diseases) by the European Cooperation in Science and Technology [60,61], about ingredients and production design of their tobacco products. This information can help to determine all characteristics of tobacco products (e.g., tobacco blend, additives or filter design) that make smoking even more harmful. Additionally, this knowledge would enable the regulation by law and the purposeful information of the public. Stronger legal regulations and public awareness will help to reduce the distribution of tobacco products worldwide to protect the human health.

The findings of this study need further investigations on comparisons of international tobacco products. Hence, studies on country-specific tobacco products will follow. 
Author Contributions: This article is part of the thesis of R.A.-Q., whereas M.B., D.K., R.M., and D.A.G. contributed significantly to the conception and design of the study. Moreover, R.A.-Q., M.B., R.M., and D.A.G. prepared the experiments, which were performed by R.A.-Q., M.B. and R.M. analysed the data. The technical support was done by M.B. The manuscript was written by M.B. and critically reviewed by all authors. All authors have participated sufficiently in the work to take public responsibility for appropriate portions of the content and agreed to be accountable for all aspects of the work in ensuring that questions related to the accuracy or integrity of any part of the work are appropriately investigated and resolved. All authors have read and approved the final manuscript.

Funding: This research received no external funding.

Conflicts of Interest: The authors declare no conflict of interest.

\section{References}

1. United States Environmental Protection Agency. Particulate Matter (PM) Basics. Available online: https: //www.epa.gov/pm-pollution/particulate-matter-pm-basics\#PM (accessed on 9 August 2019).

2. International Organization for Standardization. ISO 7708:1995. Air Quality-Particle Size Fraction Definitions for Health-Related Sampling. Available online: https://www.iso.org/obp/ui/\#iso:std:iso:7708:ed-1:v1:en (accessed on 30 March 2020).

3. Scibor, M.; Galbarczyk, A.; Jasienska, G. Living well with pollution? The impact of the concentration of PM2.5 on the quality of life of patients with asthma. Int. J. Environ. Res. Public Health 2019, 16, 2502. [CrossRef]

4. Kim, K.H.; Kabir, E.; Kabir, S. A review on the human health impact of airborne particulate matter. Environ. Int. 2015, 74, 136-143. [CrossRef]

5. Protano, C.; Manigrasso, M.; Avino, P.; Vitali, M. Second-hand smoke generated by combustion and electronic smoking devices used in real scenarios: Ultrafine particle pollution and age-related dose assessment. Environ. Int. 2017, 107, 190-195. [CrossRef]

6. Brunekreef, B.; Holgate, S.T. Air pollution and health. Lancet 2002, 360, 1233-1242. [CrossRef]

7. International Agency for Research on Cancer. IARC Monographs on the Identification of Carcinogenic Hazards to Humans. List of Classifications. Available online: https://monographs.iarc.fr/list-of-classifications (accessed on 30 March 2020).

8. Anderson, J.O.; Thundiyil, J.G.; Stolbach, A. Clearing the air: A review of the effects of particulate matter air pollution on human health. J. Med. Toxicol. 2012, 8, 166-175. [CrossRef]

9. Lim, S.S.; Vos, T.; Flaxman, A.D.; Danaei, G.; Shibuya, K.; Adair-Rohani, H.; Amann, M.; Anderson, H.R.; Andrews, K.G.; Aryee, M.; et al. A comparative risk assessment of burden of disease and injury attributable to 67 risk factors and risk factor clusters in 21 regions, 1990-2010: A systematic analysis for the global burden of disease study 2010. Lancet 2012, 380, 2224-2260. [CrossRef]

10. World Health Organization. Programmes. Air Pollution. Available online: http://origin.who.int/airpollution/ en/ (accessed on 30 March 2020).

11. Bozetti, C.; El Haddad, I.; Salameh, D.; Daellenbach, K.R.; Fermo, P.; Gonzalez, R.; Minguillón, M.C.; Inuma, Y.; Poulain, L.; Elser, M.; et al. Organic aerosol source apportionment by offline-AMS over a full year in Marseille. Atmos. Chem. Phys. 2017, 17, 8247-8268. [CrossRef]

12. Van Deusen, A.; Hyland, A.; Travers, M.J.; Wang, C.; Higbee, C.; King, B.A.; Alford, T.; Cummings, K.M. Secondhand smoke and particulate matter exposure in the home. Nicotine Tob. Res. 2009, 11, 635-641. [CrossRef]

13. Cattaneo, A.; Fermo, P.; Urso, P.; Perrone, M.G.; Piazzalunga, A.; Tarlassi, J.; Carrer, P.; Cavallo, D.M. Particulate-bound polycyclic aromatic hydrocarbon sources and determinants in residential homes. Environ. Pollut. 2016, 218, 16-25. [CrossRef] [PubMed]

14. Gerber, A.; Hofen-Hohloch, A.V.; Schulze, J.; Groneberg, D.A. Tobacco smoke particles and indoor air quality (topiq-ii)-a modified study protocol and first results. J. Occup. Med. Toxicol. 2015, 10, 5. [CrossRef] [PubMed]

15. Wasel, J.; Boll, M.; Schulze, M.; Mueller, D.; Bundschuh, M.; Groneberg, D.A.; Gerber, A. Brand cigarillos: Low price but high particulate matter levels-is their favorable taxation in the european union justified? Int. J. Environ. Res. Public Health 2015, 12, 9141-9153. [CrossRef] [PubMed]

16. Kant, N.; Muller, R.; Braun, M.; Gerber, A.; Groneberg, D. Particulate matter in second-hand smoke emitted from different cigarette sizes and types of the brand vogue mainly smoked by women. Int. J. Environ. Res. Public Health 2016, 13, 799. [CrossRef] [PubMed] 
17. Braun, M.; Fromm, E.L.; Gerber, A.; Klingelhofer, D.; Muller, R.; Groneberg, D.A. Particulate matter emissions of four types of one cigarette brand with and without additives: A laser spectrometric particulate matter analysis of secondhand smoke. BMJ Open 2019, 9, e024400. [CrossRef] [PubMed]

18. World-Bank. World Bank Country and Lending Groups. Available online: https://datahelpdesk.worldbank. org/knowledgebase/articles/906519\#High_income (accessed on 17 September 2019).

19. TA. The Tobacco Atlas, 6th ed.; American Cancer Society: New York, NY, USA, 2019; Available online: https://tobaccoatlas.org/ (accessed on 24 September 2019).

20. University of Kentucky. Kentucky Tobacco Research and Development Center. 3r4f Preliminary Analysis. Available online: https://ctrp.uky.edu/assets/pdf/webdocs/3R4F\%20Preliminary\%20Analysis.pdf (accessed on 13 August 2019).

21. Philip Morris International. Making Cigarettes. Product Ingredient Finder. Available online: https: //www.pmi.com/our-business/about-us/products/how-cigarettes-are-made (accessed on 9 August 2019).

22. Japan Tobacco Inc. What's in Our Products. Winston Red. United Arabic Emirates. Available online: http://ingredients.jti.com/per-product/UNITED-ARABIC-EMIRATES/Cigarette/Winston-Red/ (accessed on 9 August 2019).

23. Bundesministerium für Ernährung und Landwirtschaft. Tabakzusatzstoffe. Available online: https: //service.bmel.de/tabakerzeugnisse/index2.php?site_key=153 (accessed on 13 August 2019).

24. Mueller, D.; Uibel, S.; Braun, M.; Klingelhoefer, D.; Takemura, M.; Groneberg, D.A. Tobacco smoke particles and indoor air quality (topiq) the protocol of a new study. J. Occup. Med. Toxicol. 2011, 6, 35. [CrossRef]

25. Schimpf-Ing. Electronics Development. Available online: http://www.schimpf-ing.no/ (accessed on 13 August 2019).

26. Grimm Aerosol Technik Gmbh \& Co KG. Portable Laser Aerosolspectrometer and Dust Monitor Model 1.108/1.109. Available online: https://wmo-gaw-wcc-aerosol-physics.org/files/OPC-Grimm-model--1.108and-1.109.pdf (accessed on 14 August 2019).

27. British Standards Institution. BS EN 481:1993. Workplace Atmospheres. Size Fraction Definitions for Measurement of Airborne Particles. Available online: https://shop.bsigroup.com/ProductDetail/?pid= 000000000000313177 (accessed on 14 August 2019).

28. World Health Organization. WHO Air Quality Guidelines for Particulate Matter, Ozone, Nitrogen Dioxide and Sulfur Dioxide. Global Update 2005. Summary of Risk Assessment; WHO: Geneva, Switzerland, 2006; Available online: https://apps.who.int/iris/bitstream/handle/10665/69477/WHO_SDE_PHE_OEH_06.02_eng. pdf (accessed on 22 August 2019).

29. Semple, S.; Latif, N. How long does secondhand smoke remain in household air: Analysis of pm2.5 data from smokers' homes. Nicotine Tob. Res. 2014, 16, 1365-1370. [CrossRef]

30. United States Environmental Protection Agency. Department of Energy. Fuel Economy Guide. Available online: https://www.fueleconomy.gov/feg/pdfs/guides/FEG2019.pdf (accessed on 23 August 2019).

31. Braun, M.; Koger, F.; Klingelhofer, D.; Muller, R.; Groneberg, D.A. Particulate matter emissions of four different cigarette types of one popular brand: Influence of tobacco strength and additives. Int. J. Environ. Res. Public Health 2019, 16, 263. [CrossRef]

32. World Health Organization. WHO Report on the Global Tobacco Epidemic 2019. Available online: https://www.who.int/tobacco/global_report/en/ (accessed on 23 September 2019).

33. Maziak, W.; Nakkash, R.; Bahelah, R.; Husseini, A.; Fanous, N.; Eissenberg, T. Tobacco in the Arab world: Old and new epidemics amidst policy paralysis. Health Policy Plan. 2014, 29, 784-794. [CrossRef]

34. Al-Houqani, M.; Ali, R.; Hajat, C. Tobacco smoking using midwakh is an emerging health problem-Evidence from a large cross-sectional survey in the United Arab Emirates. PLoS ONE 2012, 7, e39189. [CrossRef]

35. Agaku, I.T.; Filippidis, F.T.; Vardavas, C.I.; Odukoya, O.O.; Awopegba, A.J.; Ayo-Yusuf, O.A.; Connolly, G.N. Poly-tobacco use among adults in 44 countries during 2008-2012: Evidence for an integrative and comprehensive approach in tobacco control. Drug Alcohol Depend. 2014, 139, 60-70. [CrossRef]

36. Al-Houqani, M.; Leinberger-Jabari, A.; Al Naeemi, A.; Al Junaibi, A.; Al Zaabi, E.; Oumeziane, N.; Kazim, M.; Al Maskari, F.; Al Dhaheri, A.; Abdel Wareth, L.; et al. Patterns of tobacco use in the United Arab Emirates healthy future (UAEHFS) pilot study. PLoS ONE 2018, 13, e0198119. [CrossRef]

37. R.J. Reynolds Tobacco Company. Commercial Integrity. Tobacco Product Ingredients. Available online: https://www.rjrt.com/commercial-integrity/ingredients/ (accessed on 4 September 2019). 
38. O'Connor, R.J.; Wilkins, K.J.; Caruso, R.V.; Cummings, K.M.; Kozlowski, L.T. Cigarette characteristic and emission variations across high-, middle- and low-income countries. Public Health 2010, 124, 667-674.

39. Song, M.A.; Benowitz, N.L.; Berman, M.; Brasky, T.M.; Cummings, K.M.; Hatsukami, D.K.; Marian, C.; O'Connor, R.; Rees, V.W.; Woroszylo, C.; et al. Cigarette filter ventilation and its relationship to increasing rates of lung adenocarcinoma. J. Natl. Cancer Inst. 2017, 109, djx075. [CrossRef]

40. Rustemeier, K.; Stabbert, R.; Haussmann, H.J.; Roemer, E.; Carmines, E.L. Evaluation of the potential effects of ingredients added to cigarettes. Part 2: Chemical composition of mainstream smoke. Food Chem. Toxicol. 2002, 40, 93-104. [CrossRef]

41. Wertz, M.S.; Kyriss, T.; Paranjape, S.; Glantz, S.A. The toxic effects of cigarette additives. Philip morris' project mix reconsidered: An analysis of documents released through litigation. PLoS Med. 2011, 8, e1001145. [CrossRef] [PubMed]

42. Gaworski, C.L.; Dozier, M.M.; Gerhart, J.M.; Rajendran, N.; Brennecke, L.H.; Aranyi, C.; Heck, J.D. 13-week inhalation toxicity study of menthol cigarette smoke. Food Chem. Toxicol. 1997, 35, 683-692. [CrossRef]

43. Gerharz, J.; Bendels, M.H.K.; Braun, M.; Klingelhofer, D.; Groneberg, D.A.; Mueller, R. Particulate matter emissions of different brands of mentholated cigarettes. J. Air Waste Manag. Assoc. 2018, 68, 608-615. [CrossRef]

44. Keith, C.H.; Derrick, J.C. Measurement of the particle size distribution and concentration of cigarette smoke by the "conifuge". J. Colloid Sci. 1960, 15, 340-356. [CrossRef]

45. Nazaroff, W.W.; Klepeis, N.E. Environmental tobacco smoke particles. In Indoor Environment: Airborne Particles and Settled Dust; Morawska, L., Salthammer, T., Eds.; Wiley-VCH Verlag GmbH \& Co. KG: Weinheim, Germany, 2003; pp. 245-274.

46. Guerin, M.R.; Higgins, C.E.; Jenkins, R.A. Measuring environmental emissions from tobacco combustion-sidestream cigarette-smoke literature-review. Atmos. Environ. 1987, 21, 291-297. [CrossRef]

47. Ueno, Y.; Peters, L.K. Size and generation rate of sidestream cigarette-smoke particles. Aerosol Sci. Technol. 1986, 5, 469-476. [CrossRef]

48. Becquemin, M.H.; Bertholon, J.F.; Bentayeb, M.; Attoui, M.; Ledur, D.; Roy, F.; Roy, M.; Annesi-Maesano, I.; Dautzenberg, B. Third-hand smoking: Indoor measurements of concentration and sizes of cigarette smoke particles after resuspension. Tob. Control 2010, 19, 347-348. [CrossRef]

49. Haustein, K.O.; Groneberg, D. Tobacco or Health? Springer: Heidelberg, Germany, 2010.

50. Ohlwein, S.; Kappeler, R.; Kutlar Joss, M.; Kunzli, N.; Hoffmann, B. Health effects of ultrafine particles: A systematic literature review update of epidemiological evidence. Int. J. Public Health 2019, 64, 547-559. [CrossRef]

51. European Committee for Standardization. CEN/TC 264-Air Quality EN 12341. Ambient Air-Standard Gravimetric Measurement Method for the Determination of the pm10 or pm2.5 mass Concentration of Suspended Particulate Matter. Available online: https://standards.cen.eu/dyn/www/f?p=204:110:0:::: FSP_PROJECT,FSP_ORG_ID:29133,6245\&cs=1DC6EB16DD302E384B46A7097AAC67CB5 (accessed on 3 September 2019).

52. United States Environmental Protection Agency. List of Designated Reference and Equivalent Methods. Available online: https://www3.epa.gov/ttn/amtic/files/ambient/criteria/AMTIC_List_June_2017_update_619-2017.pdf (accessed on 3 September 2019).

53. Grimm, H.; Eatough, D.J. Aerosol measurement: The use of optical light scattering for the determination of particulate size distribution, and particulate mass, including the semi-volatile fraction. J. Air Waste Manag. Assoc. 2009, 59, 101-107. [CrossRef] [PubMed]

54. Fromme, H.; Twardella, D.; Dietrich, S.; Heitmann, D.; Schierl, R.; Liebl, B.; Ruden, H. Particulate matter in the indoor air of classrooms-exploratory results from Munich and surrounding area. Atmos. Environ. 2007, 41, 854-866. [CrossRef]

55. International Organization for Standardization. ISO/TR 17219:2013(EN). Review of Human Smoking Behaviour and Recommendations for a New ISO Standard for the Machine Smoking of Cigarettes. Available online: https://www.iso.org/obp/ui/\#iso:std:iso:tr:17219:ed-1:v1:en (accessed on 4 September 2019).

56. World Health Organization. WHO Toblabnet Official Method SOP 01. Standard Operating Procedure for Intense Smoking of Cigarettes. Available online: https:/apps.who.int/iris/bitstream/handle/10665/75261/ 9789241503891_eng.pdf;jsessionid=259B4A859847A91ADE114A74F9A251CB? sequence=1 (accessed on 4 September 2019). 
57. Sahu, S.K.; Tiwari, M.; Bhangare, R.C.; Pandit, G.G. Particle size distribution of mainstream and exhaled cigarette smoke and predictive deposition in human respiratory tract. Aerosol Air Qual. Res. 2013, 13, 324-332. [CrossRef]

58. Nowak, D.; Raupach, T.; Radon, K.; Andreas, S. Passivrauchen als gesundheitsrisiko. Der Pneumologe 2008, 5, 386-392. [CrossRef]

59. Braun, M.; Langenstein, A.; Klingelhofer, D.; Zulauf, N.; Muller, R.; Groneberg, D.A. Particulate matter emissions of less harmful-looking super-slim size cigarettes appealing to women: A laser spectrometric analysis of second-hand smoke. Environ. Sci. Pollut. Res. Int. 2020, 27, 1069-1077. [CrossRef]

60. DiMoPEx. Diagnosis, Monitoring and Prevention of Exposure Related Non-Communicable Diseases, DiMoPEx (CA 15129). Available online: http://dimopex.eu/about/ (accessed on 12 September 2019).

61. Budnik, L.T.; Adam, B.; Albin, M.; Banelli, B.; Baur, X.; Belpoggi, F.; Bolognesi, C.; Broberg, K.; Gustavsson, P.; Goen, T.; et al. Diagnosis, monitoring and prevention of exposure-related non-communicable diseases in the living and working environment: Dimopex-project is designed to determine the impacts of environmental exposure on human health. J. Occup. Med. Toxicol. 2018, 13, 6. [CrossRef]

(C) 2020 by the authors. Licensee MDPI, Basel, Switzerland. This article is an open access article distributed under the terms and conditions of the Creative Commons Attribution (CC BY) license (http://creativecommons.org/licenses/by/4.0/). 